\title{
INDIGENOUS KNOWLEDGE AND NUTRIENT MANAGEMENT PRACTICES OF FARMERS GROWING SWEETPOTATO IN THE UPLANDS OF PINABACDAO, SAMAR
}

\author{
ANABELLA B. TULIN and VICTOR B. Asio \\ Visayas State University, Visca, Baybay, Leyte
}

\section{ABSTRACT}

This study aimed at determining if the sweetpotato growers in the locality of Parasanon, Pinabacdao, Samar possess certain local knowledge about their soil and crops, particularly sweetpotato: Informal and formal interviews were the primary methods used in gathering information for the study.

The demographic traits of the farmers clearly differed but they adhered to the same knowledge system regarding the attributes of the soil in their locality and the condition of growth of their sweetpotato plants. Using their native dialect, the farmers have a soil classification scheme based on textual characteristics and certain indicators of soil fertility and plant health. Moreover, the farmers are also aware of certain problems connected to their soils or crops but these do not bother them because they have the experience in circumventing field-related problems.

Generally, the upland farmers of Pinabacdao do not use degraded soils for sweetpotato production. They ordinarily leave the area temporarily and relocate to more fertile grounds in the forest edges if they find their soils to be no longer productive. None among the local farmers use any of the improved sweetpotato production technologies which were shown or given to them by technicians connected either to the $R \& D$ project conducted previously in the locality or the Department of Agriculture.

KEY WORDS: Traditional knowledge, soil conservation, soil fertility, Samar 


\section{INTRODUCTION}

The best practice in development calls for projects that will benefit all stakeholders and results in a mutually sustainable socio-economic and natural environment. This needs the integration of both local/traditional knowledge and technology in answering certain problems confronting our environment. Many governments, development agencies, and corporations are interested in the principles that underpin indigenous peoples' traditional knowledge systems (Emery, 2000).

Traditional knowledge is more than a simple compilation of facts, practices and beliefs drawn from local, and often remote environments. It is a complex and sophisticated system of knowledge drawing on centuries of wisdom and experience (Emery, 2000). In fact, Nazarea-Sandoval (1991) espouses that its documentation is essential in conserving crop biodiversity which is rapidly being lost. Lamola (1992) further reports that in addition to local criteria for discrimination, classification, and evaluation, small scale farmers in developing countries also breed local crop varieties for improved production using informal system. Prain (1998) also confirmed in the case of sweetpotato the presence of considerable dynamism in the local gardens with many addition and losses of accessions of sweetpotato.

Rootcrops like sweetpotato and cassava are important sources of food and income not only for the marginal and subsistent farmers but also as a major source of revenues for the country. It is usually cultivated in the upland environments and they perform multiple functions which include as staple food, subsistence food, cash crop or commercial crop (Prain, 1995; Castillo, 1995). Likewise, they cover emergency circumstances, seasonal flexibility, nutritional supplements, food diversity and processing functions (Prain, 1995).

In documenting the indigenous knowledge system on sweetpotato of Maranao Muslims in Northern Mindanao, Bautista and Amihan-Vega (1991) found out that the Maranao farmers have distinct sweetpopato farming 
practices. However, only the old farmers continue using them. Likewise, they have unique ways of naming sweetpotato cultivars. Thus, it is also worth noting to study indigenous knowledge systems involving not only different minority groups but different farming environments as well. One area that needs to be studied is the production of sweetpotato under upland environment, which constitutes the major soils planted to sweetpotato in the Philippines.

This study was conducted on the premise that traditional knowledge is an important input to be considered in the overall understanding and development of sweetpotato grown in degraded upland soil. Sweetpotato is one of the principal crops grown in Pinabacdao, Samar and is considered as an important staple food of the local people. It is a major source of incone because of its ready market either in the same locality or in other places in Samar or Leyte. For years, the production of sweetpotato has been subsistent in nature and this remained so despite of a research and development $(R \& D)$ project that had been conducted in the area in the past which used improved production technologies for the crop.

\section{Objectives of the Study}

The general objective of the study was to determine whether the sweetpotato growers in the locality of Parasanon, Pinabacdao, Samar possess certain indigenous knowledge system about the soil and the crop they grow and whether they have nutrient management practices, they being traditional growers of the crop. In more specific terms, the following were the objectives of the study:

1. To validate if the sweetpotato growers in Pinabacdao, Samar use degraded uplands as sweetpotato production areas;

2. To document and assess local integrated nutrient management (INM) practices for sweetpotato production under - hillyland condition; 
3. To identify knowledge gaps and other R \& D needs of INM for sustainable sweetpotato production under hillyland condition;

4. To document the impact of a previous project on sweetpotato technology dissemination on the sweetpotato production of local farmers.

\section{METHODOLOGY}

The research team composed of crop, soil and social science researchers selected Parasanon as the locale of the study for two reasons: (1) it has a very notable record of growing sweetpotato both for household consumption and for the market, and, (2) the place was the site of a foreignfunded project on rootcrops technology transfer whose impact on the local sweetpotato growing needs to be assessed.

The team visited the locality a number of times and conducted informal and formal interviews and consultations with sweetpotato growing farmers who were the main informants of the study. The first time farmers were formally met was during a pre-arranged schedule in which the research team surveyed the local knowledge of the farmers concerning soil condition and crop health. Later visits, however, were scheduled during the market day in Parasanon when farmers normally go down to the barangay center from their respective farms to sell their produce. This was done because many farmers were not usually available on ordinary days due to their preoccupation in the farm. Also, a number of them could not be reached ordinarily in their homes because of the considerable distance between their farms and the barangay center. Furthermore, going to distant locations in the locality entailed substantial risk due to unfavorable peace and order condition in the area. In fact, direct field observations related to the study were only made on farms not far from the population centers or the national highway. 
The formal interview schedule had four main aspects which included the description of the farmer's field, the crops usually planted, the soil nutrients and the field management practices followed by the farmers. Under each aspect were sets of specific questions that the farmer-respondents had to respond objectively.

\section{RESULTS AND DISCUSSION}

\section{Area Description}

Pinabacdao is a municipality in Samar (Western Samar previously) which is located about $54 \mathrm{~km}$ north-west of Tacloban, Leyte and about the same distance to the south of Catbalogan, Samar. The municipalities bounding Pinabacdao are Calbiga in the north, Sta. Rita in the south, Villareal in the southwest and Borongan in the east. Pinabacdao has 24 barangays or villages, five of which are situated along the coast of Maqueada Bay (Aganon and Bautista-Tulin, 1997). The municipality has a total land area of 20,000 hectares. Of this, 11,248 hectares are arable. The major agricultural crops include rice ( $365 \mathrm{ha}$ ), corn ( $319 \mathrm{ha}$ ), rootcrops (529 $\mathrm{ha})$, and coconut $(5,125 \mathrm{ha})$. Its topography is generally hilly with occasional plain that is mostly traversed by a national highway. Only about $56 \%$ of the total land area of municipality is cultivable. In terms of area planted, the main agricultural crops of Pinabacdao on a decreasing hectarage basis are coconut, rootcrops, corn and rice (Dagoy, et al., 1990). Rice occupies most of the plains while coconut, the greater part of the hilly areas. The rootcrops grown are taro, sweetpotato, and cassava; taro being the major cash crop, sweetpotato as important supplemental source of food and income, and cassava as alternative food. The rootcrops, corn and upland rice are planted in small field patches along hillsides in which primary kind of soil is clay loam belonging to the Alfisol type.

The province of Samar has no distinct dry and wet season. Rainfall is more or less evenly distributed throughout the year. The soil has very slow permeability hence, it is highly prone to surface runoff. Cogon, (Imperata cylindrica) and "talahib" (Saccharum spontaneum) are predominant grasses that cover in clumps most of the uncropped areas especially the low 
lying ones where the terrain undulates. The poor soil condition and the apparent lack of proper soil management practices by the farmers in the area could be the main reasons why its soils are generally considered degraded.

The study concentrated on the sweetpotato growers living in the vicinity of Barangay Parasanon and its adjoining areas who often come to Parasanon during market days. About $75 \%$ of the people living in the locality including those who sell their farm produce in the same barangay belong to the low income group. Most of them are subsistent farmers who depend largely on hired labor and farm produce for principal income. Family members including primary school-aged children are the common source of labor for farm production.

In the early 1990s, Parasanon and its joining barangays were selected as pilot size of a project entitle, "Development of Effective Technology Transfer Scheme for Appropriate Root Crop Technologies on Production, Processing and Utilization at the Community Level". The project aimed among others to introduce sweetpotato technology which included newly developed varieties to the local farmers for adoption.

\section{Characteristics of the sweetpotato growers}

\section{Demographic description}

The farmers who contributed information to this study were from 20 to 73 years of age, with majority of them between 40 and 55 . They had different educational attainments although most of them were only up to the elementary level. All of them have been into farming for a number of years already when the study was conducted, i.e. $15-53$ years to be exact. in fact, for all of them farming was the main source of livelihood. Their association with sweetpotato ranged from 5-53 years although some of them had refrained from growing the crop for sometime because of their shifting priority on the kind of crop they plant on a certain season or year. At present, the area that the farmers devote for sweetpotato production 
ranges from a garden size of about $100 \mathrm{~m}^{2}$ to a plantation scale of $2,500 \mathrm{~m}^{2}$ more or less. Their ability to maintain a larger crop production area depends on the availability of labor including that which comes from the members of the family. For the farmer respondents, the number of children ranged from $0-11$ with 16 years as the average age. Majority of the farmers were tenants with only few of them owning the field the toil (Escalada, et al., 1994)

\section{Exposure to agricultural technologies}

Majority of the farmers involved in the study received direct information about the sweetpotato technologies disseminated by the Philippine Root Crop Research and Training Center in VSU (formerly ViSCA) through the International Development Research Center (IDRC)-funded project that was conducted in the area at an earlier period. Many of them were trained in sweetpotato production and received planting materials of developed sweetpotato varieties. However, those that adopted the ViSCA-developed varieties did not continue growing them for the following reasons; (1) the varieties needed to be harvested only once, (2) they could not withstand the long dry period in the area, (3) they required fertilizer and pesticide inputs, (4) they needed to be intensively cleaned of weeds, (5) their storage roots were wet when cooked, (6) they taste too sweet, (7) they got rotten easily after harvest, and (8) they did not have good market price.

\section{Choice of sweetpotato varieties}

During market days in the locality, when available, the common varieties of sweetpotato for sale are the traditional ones; either Kaangi or Kasapad plus one or two other indigenous varieties which are already extinct like Karingkit or Inanahaw. These varieties are preferred by the local people over the newly developed ones because they produce storage roots along their vines aside from those at the base of the plants, enabling them to harvest roots a number of times. These roots have good eating quality. Beside, these varieties have been proven to be tolerant to drought amid diseases. 
Its vines extend long from the base so that in effect, the plants cover the field in just a matter of weeks after planting. On the part of the farmers, this characteristic is advantageous to them because it helps reduce labor in controlling weeds.

\section{Cropping system}

The farmers in the locality of Parasanon do not only grow sweetpotato but other crops as well, whether in association with sweetpotato as an intercrop or as rotation or relay crop. The other crops that are grown predominantly, regardless of the size of the area planted to them are taro, cassava, upland rice, yautia, pineapple, banana, and corn. Farmers differed in what they have as major crop. Some have upland rice, some have taro and others, sweetpotato. There seemed to be no common crop which they considered secondary although a number of them pointed at sweetpotato. The farmers also varied in the purpose of growing their primary or secondary crop - either strictly for home consumption, market or both. Many of those who raised crops mainly for home consumption, nevertheless, sold whatever they had as excess of the household need. Meanwhile, those that had premeditated aim to sell part of their produce from selling anything when their harvest was short of the family's need. These facts indicate that farmers in Pinabacdao actually cultivate crops basically for household needs. The other purpose they may have in raising crops is highly dependent on the outcome of their primary intention.

Majority of the farmer respondents claimed to follow a crop-fallow-crop cycle of farming although some practice continuous cropping system. The fact, however, is that all of them practice the same cropping system. What is usually done is they clear an area from natural vegetation and then plant it with certain crop or crops in a mixed stand. If they observe that the soll is still capable of supporting favorable growth, they replant the same area. They do the same thing until the growth of the crop becomes clearly impaired and yield declines due to soll infertility. Once this is observed, they simply leave the field. As far as the farmers were concerned, fallowing normally takes three to seven years before the land is again reclaimed for cultivation. 


\section{Farmers' Indigenous Knowledge About Their Soil and Crop}

\section{Soil classiffication, fertility and slope}

The farmers in Parasanon have their own knowledge system about various aspects of the soil; classification, fertility, and topography. In fact, their indigenous knowledge related to the soil is implanted in the local Waray dialect which contain specific classificatory or descriptive terms like barason for sandy, batohon for stony, patag for plain, etc.

The local classification used by the farmer respondents for their soils is mainly based on the soil texture as presented in Table 1 . With this classification system, the farmers could well indicate likewise where the particular kind of soil is specifically located in their locality and the inherent characteristics particular to the kind of soil.

Table 1. Ethnological classification of the soil by the farmers growing sweetpotato in the locality of Parasanon, Pinabacdao, Samar

\begin{tabular}{lll}
\hline & \multicolumn{1}{c}{ Specific } & \multicolumn{1}{c}{ General } \\
\cline { 2 - 3 } Classification & Location & \multicolumn{1}{c}{ Characteristics/Description } \\
\hline $\begin{array}{l}\text { Barason (Sandy) } \\
\text { Batohon (Stony, } \\
\text { gravely) }\end{array}$ & $\begin{array}{l}\text { Riverside } \\
\text { Near river or } \\
\text { slope }\end{array}$ & $\begin{array}{l}\text { Encourage good growth of any crop } \\
\text { Top soil is shallow. Stony subsoll. Any } \\
\text { crop planted in it wilt faster a shori dry } \\
\text { spell } \\
\text { Hald. Sticky/slippery when wet. Friable } \\
\text { when dry. }\end{array}$ \\
\hline
\end{tabular}

Because of the absence of a better kind of soil such as loam or sandy loam and the inadequacy of barason areas, which is the best alternative in the locality of Parasanon, crop production is commonly done in the hillsides where the soil is generally clayey. The lack of adequate vegetation cover in many of the cultivated hillsides induced erosion and turned the fields into stony patches of the top soil and the 
subsequent outcropping of stones present in the subsoil. Despite this minimal vegetative cover, local farmers did notseem to be disturbed by the erosion problem although they are aware of its consequences on the general productivity of their lands.

The prevalent concept of soil fertility given by the farmers during the survey was that the farmlands near the barangay or center of population are generally poor in nutrient content because of overuse, whereas, those that are farther away inland are fertle because the lands are seldom used for crops.

The farmers attributed the rehabilitation of a fallowed field to the organic matter that comes from fallen leaves and other plant materials that decompose on the ground. It was a widespread belief among the farmer respondents that leaving the field for a few years will enable the soil to accumulate organic matter and thus, its ability to support vigorous growth of crops is restored. Some of the farmers were quick to underscore, however, that accumulation of organic matter is not promoted by just any kind of vegetation growing over a certain field. Cogon and talahib are considered poor in contributing organic matter to the soil while shrubs and trees are good depositors of the same.

The indicators of soil fertility observed by the farmers in the locality included soll color, texture, and the kind of vegetation growing in the field (Table 2). Under any of these indicators, the farmers appeared well versed in differentiating a fertile soil from an infertile one by merely describing them generally. Furthermore, the local farmers could promptly point out the causes why a certain soil possesses a particular color or textural characteristics.

The dark color associated with fertile soil is attributed to the presence of decayed plant materials. Accordingly, the darker the soil color, the more organic matter it contains and the richer it is for plant growth. The farmers believed also that it is organic matter that makes naturally hard soil brittle and friable. They also think that reddening of a soil is not only an indication of its poor nutrient content but of heavy erosion as well, with regard to the 
local concept of the topography of their fields, the farmers had in mind the slope of the soil which they termed kabakilid. Having the flat or plain ground as their basis, they classify the slope of their lands using definitive local terms with their corresponding description for each classification (Table 3). It was through the description given by the farmers that the inclination of their lands was determined by the researchers. The suggested percentage slope for each of their local classification was noted by the farmers themselves to be the actual slope of their fields.

There was a common understanding among the farmers that soils under any degree of slope, except that of the plain, are subject to erosion, commonly caused by heavy rains. The presence of soil deposits (agan-an) at the base of the slope, the outcropping or protrusion of rocks or stones on the soil surface, and cracking of the soil were the key indicators of soil erosion given. They generally attributed soil erosion in their fields to two factors; the lack or absence of trees and other vegetative cover on the hilltops and hillsides, and heavy rainfall in the area especially during the rainy season.

Table 2. Local indicators of soil fertility and the characteristics associated with the fertile or infertile soil

\begin{tabular}{|c|c|c|}
\hline \multicolumn{3}{|c|}{ General Description } \\
\hline Indicator & Fertile Soll & Infertile Soil \\
\hline Color & Blackish; dark brown & Pale brown; reddish \\
\hline Texture & Fine & Coarse; hard \\
\hline Vegetation & $\begin{array}{l}\text { Mixed stand of different } \\
\text { species; combination of } \\
\text { shrubs, trees and vines }\end{array}$ & $\begin{array}{l}\text { Predominantly cogon } \\
\text { and talahib }\end{array}$ \\
\hline
\end{tabular}


Table 3. Classification of the slope of the land by farmers using local technologies

Slope Classification

Description

Percent Siope

\begin{tabular}{lll}
\hline Patag & Plain; flat & $\sim 0-5$ \\
Anay-ay & undulating & $\sim 6-10$ \\
Higad-higad & rolling & $\sim 15-50$ \\
Higad & steep & $>50$ \\
\hline
\end{tabular}

Although it was widely regarded that erosion contributes to soil degradation and eventual loss of soil fertility, the farmers generally did not seem to be bothered by the problem. In fact, none of them had adopted the technology of planting vetiver or other grasses along the contour of their fields to control erosion as had been shown to them in demonstration plots of IDRC-funded project mentioned earlier. Their lack of concern to maintain the fertility of the soll, i.e., to check soil erosion for example, is pervasive due to the fact that they could easily transfer and relocate their farms to other areas in the same locality. In moving out from their degraded fields, the farmers either open new areas or go back to his previously cropped area that had been already rehabilitated by natural vegetation after some years of fallow. This practice of opening new lands for farming every now and then may have contributed to the shrinking of the forest in Samar. One farmer, in fact, had a farm about five or seven kilometers away from his residence because unused lands are those that are farther away from the population centers.

Concerning soil erosion control, a farmer who did not like to relocate his farm to a more distant site showed regard for his soil, in that, he checked or controlled soil erosion by lining up banana stalks across the slope of his field during the rainy season. 
It could be delved from the information gathered that local farmers generally do not have initiative to protect and preserve their soil resource basically on the reason that unclaimed uncropped areas are available anytime notwithstanding their distance from population centers. Furthermore, the information suggest that the technology using contour planting of deep rooted grasses to control soil erosion was not adopted by the local farmers for long. The technology was only good when the technology dissemination project was still enforced.

Crop health. When asked about their idea of crop health, farmers considered plant growth (tubo hiton tanum) as an important indicator. The common distinguishing characters of a healthy and unhealthy plant under the indicators given is presented in Table 4, together with the perceived causes of plant unhealthiness.

In a similar study conducted by Tulin et. al., (2004) involving commercial sweetpotato farmers in Dulag, Leyte, they reported that in matching the farmer's indigenous knowledge on crop health with the researchers' assessment in the laboratory, the farmers have a good perception of a healthy and unhealthy crop. However, they could not pinpoint which specific nutrient is deficient or not but they have more or less a general perception of crop performance based on leaf color and leaf size.

Table 4. Indicators of crop health and the main distinguishing characters of a healthy plant under each indicator

\begin{tabular}{llll}
\hline \multicolumn{1}{c}{ Indicator } & \multicolumn{1}{c}{$\begin{array}{c}\text { Healthy } \\
\text { Crop }\end{array}$} & \multicolumn{1}{c}{$\begin{array}{c}\text { Unhealthy } \\
\text { Crop }\end{array}$} & \multicolumn{1}{c}{$\begin{array}{c}\text { Perceived } \\
\text { Cause }\end{array}$} \\
\hline Leaf color & Dark green & yellowish & Lack of nutrients \\
Leaf size & Large; thick & Small; thin & Lack of nutrients \\
Rate of growth & fast & slow & Lack of nutrients \\
Storage root size & Mostly large & Mostly small & Lack of nutrients \\
Presence of pests & Usually more & Usually less & Succulence of leaves \\
\hline \hline
\end{tabular}


The common solution practiced by Parasanon farmers to mitigate poor crop health was leaving or abandoning (fallow) the area and allow it revegetate by trees and other naturally growing plant species. The number of years of fallow for a field normally ranged from 4-7 years after which it is again utilized by cutting down first all existing trees and other vegetation. Other farmers, instead of leaving the field, changed their crop and planted either banana, peanut, pineapple or cassava. It was a general opinion of the farmer respondents that continuous planting of sweetpotato on the same field results in a decline of growth and yield. The farmers, however, pointed to loss of soil nutrient as the possible cause of poor crop growth. The idea of allelopathy, which is true in sweetpotato (Pardales, 1993), was not known to any of the farmers although they had previous experiences of declining yield in repeatedly cropped field.

Sweetpotato as a crop. The farmers' popular idea about sweetpotato as a crop in terms of its relationship with the soil is that it prevents erosion of the soil even during heavy rains. This observation was accurate from the researchers' point of view because the traditional varieties that the farmers are commonly planting had viny stature such that they cover the ground well, soften the impact of rains, and check water run-off.

The idea that sweetpotato is a soil-nutrient depleting crop had never entered the mind of the local growers of the crop. In fact, they claimed that if it were true, they would still never consider it as a problem primarily because it is seldom that they plant sweetpotato successively in the same area. As far as the farmers' experience is concerned, their reason for not planting sweetpotato in succession are twofold: (1) the storage roots of the succeeding sweetpotato crop do not grow big, and (2) the storage roots of the following crop cannot be eaten nor sold due to sweetpotato weevil infestation. The farmers' first reason is legitimate from scientific point of view. It was found by Pardales (1993) that sweetpotato causes growth inhibition to itself if it is planted in close succession over the same area due to allelophatic effect. However, this is lost, if the land is left idle for a few months or planted with another crop. 
On the other hand, the second reason is especially true if the harvest of the second crop happens during the dry season when sweetpotato becomes vulnerable to the attack of sweetpotato weevil. During dry season, the soil at the base of sweetpotato plants usually cracks due to the enlargement of the storage roots especially if the soil is hard or clayey. The crack serves as the avenue for the insect to reach the enlarged roots. Wetting the soil by rainfall or irrigation helps close soil fissures and make sweetpotato storage roots inaccessible to sweetpotato weevils (Pardales and Cerna, 1987).

The farmers considered soil management and crop health as critical factors for sweetpotato and for other crop production. Nevertheless; they claimed that (they do not mind) they ignored practicing or maintaining any of practices related to these because of the fact that their production is only small scale. The farmers showed more interest in managing their soil well and improving plant health only if they grow the crop in a semicommercial or commercial scale and when they put capital investment on it, like what they do with corn or other cash crops.

The farmers did not have specific soil management and crop health problem with regard to their sweetpotato production. Nevertheless, they expressed their willingness to collaborate or cooperate with researchers on whatever activity that needs to be done to improve the production of their crop.

\section{Local Practices of Nutrient Management for Sweetpotato}

\section{Use of commercial fertilizer}

All the farmer respondents indicated that soil fertility is important because it makes sweetpotato grow well and give good yield. In fact, many of them have seen how the crop grows under a well-fertilized condition in the demonstration plots established by the sechnology dissemination project mentioned earlier. However, none among the farmer respondents used any kind of commercial fertilizer for sweetpotato. 
They also pointed out that they do not have any specific practice that could be considered to improve or maintain soil fertility except leaving the unproductive lands temporarily (fallowing) to allow it to recover by natural means. The local farmers know fully well though that lack of nutrients in the soil is a problem. The reasons given for not using fertilizer on sweetpotato were: (1) they have no money for buying fertilizer, (2) it is difficult to transport fertilizer to their field which is very far from the barangay center or the highway, (3) fertilization is not necessary since their field can still sustain good crop growth, (4) they could easily relocate theircrop cultivation in the farms with better soil conditions if their sweetpotato crop grows and yields poorly, and, (5) fertilization is not practical because their sweetpotato production is only on small scale.

Nobody among the respondents use animal manure as fertilizer. This is primarily because there is not much supply of it locally. Although the farmers do not normally use animal manure, some of them believe that animal manure is a source of certain diseases that infect sweetpotato. Others considered it unsanitary to use them for crop production.

Integrated Nutrient Management (INM). From the interviews, nothing is found from the respondents that could be directly considered as an INM practice for sweetpotato except fallowing their fields if they are no longer productive. Indirectly, however, the only thing that could be taken into account as an INM strategy by the farmers for sweetpotato is leaving the uprooted weeds at weeding time scattered on the surface of the ground to let it decay and be incorporated eventually into the soil. For some farmers, the practice was used to heap the grasses around the planting mound for the reason of suppressing subsequent growth of weeds. At harvest, the sweetpotato vines and other plant residues are also left on the ground to decompose. Strictly speaking, the fact that farmers do not normally plant sweetpotato over the same area in succession makes the purpose of letting weeds and plant materials decompose and affect nutrient recycling . This practice will encourage the accumulation of organic matter in the soil which will be advantageous to succeeding croppings of sweetpotato after the fallow period. 


\section{Main Production in Sweetpotato Production}

For the farmers, in Parasanon, their main problem with regard to sweetpotato production is lack of financial resource for labor to keep their sweetpotato field weed-free. Since the family members are the main provider of labor, the father or head of the family tilled only certain area of land that the other members of the family could help maintain, especially the control of weeds. Almost all of the farmer respondents have the respective wife help them in some farm chores. The ordinary work for the wives are planting, weeding, and harvesting. Among these activities, the farmer husbands see weeding as the most demanding for wives or children. The parents of the farmers who are still capable of farm work also help in the field.

\section{CONCLUSION AND RECOMMENDATIONS}

The farmers growing sweetpotato in Parasanon, Pinabacdao, Samar possess a local knowledge system with regard to the nature of the soil and the culture their sweetpotato crop. Although they are well aware of the effect of certain unfavorable soil or crop condition like the sloppiness of their field (which favor soil erosion) or the fertility condition of their soil (which needs to be improved or maintained), the farmers are not concerned at all. This is due to the fact that they could readily leave their infertile fields and open a new land, usually in the periphery of the forest, and use it for crop production. It follows therefore, that the upland farmers in Pinabacdao do not actually use degraded areas for sweetpotato production. Instead, they relocate in areas where the soil is relatively fertile and productive. Richer areas are those in the forested inlands so that the use of these areas for crop production causes deforestation. In effect, this pushes the forest further away. One thing that this situation apparently suggests is that the population of the locality is still at a level where it does not impose yet pressure on the land. 
Technologies on sweetpotato production demonstrated before them under a previous project did not prove sustainable on the part of the local farmers, including the high yielding sweetpotato varieties. This could be due to the fact that the breeding objectives of the researchers did not consider farmers or consumers' feedback as to the kind of variety that is preferred for planting or consumption. The continuous use of the traditional sweetpotato varieties would attest to this. The implication that this condition may bring us narrowness of diversity in the field because the farmers are left with few options in the cholce of a variety to plant. Concerning soil and crop management like the use of contour plants to check soil erosion, the reason for non-adoption could be a blend of resource unavailabity and attitudinal.

\section{LITERATURE CITED}

AGANON, C., AND BAUTISTA-TULIN A. 1998. Participatory Approaches to Integrated Nutrient Management in the Philippines. In: Sustainable Livelihood for Rural Households: Contributions from Rootcrop Agriculture. UPWARD, Los Baños, Laguna. pp. 111-136

BAUTISTA, A.T., AND B. AMIHAN-VEGA. 1991. Indigenous knowledge systems on sweetpotato farming among Maranao Muslims in Northern Mindanao. In: Proceedings during the $2^{\text {nd }}$ UPWARD International Conference, 1991. Los Baños, Laguna, Philippines

DAGOY, S.C., J.L. BACUSMO, J.R. ROA, D.M. CAMPILAN, F.G VILLAMAYOR, JR., G.D. MEROY, R.T. REPULDA AND R.S. LAGUNA. 1990. Rapid rural appraisal of four Barangaya of Pinabacdao, Samar. Visayas State College of Agriculture, ViSCA, Baybay, Leyte. 39pp.

CASTILLO, G.T. 1995. Secondary crops in primary functions: The search for systems, synergy and sustainability. UPWARD Working Paper Series No. 2. UPWARD, Los Baños, Laguna. Philippines 
EMERY, A.R. 2000. Intergrating Indigenous Knowledge in Project Planning and Implementation. World Bank, IDRC, 173pp.

ESCALADA, M.M., D.M. CAMPILAN AND E.A. GUNDAYA. 1994. Diffusion mechanisms for improved sweetpotato varieties in upland communities: Lessons from the Field. Report of an IDRC-funded project. Visayas State University, Visca, Baybay, Leyte. 77pp.

LAMOLA, L.M. 1992. Linking the formal and informal sectors in plant genetic resources conservation and utilization. White Paper 92-1. Drake University Law School, Agricultural Law Center, Des Moines, lowa

NAZAREA-SANDOVAL, V. 1991. Memory banking of indigenous technologies associated with traditional crop varieties. A focus on sweetpotatoes. In: Proceeding on Sweetpotato Cultures of Asia and the South Pacific. Second UPWARD International Conference. Los Baños, Laguna. Philippines

PARDALES, J.R., JR. 1993. Inhibitory influence of sweetpotato-used soil on the root growth of sweetpotato. Phil. Journ. Crop Sci. 18: $181-185$

PARDALES, J.R., JR., AND A.F. CERNA. 1987. An agronomic approach to control sweetpotato weevil. Tropical Pest Management. 33:32-34

PRAIN, G. 1995. Sweetpotato in Asian production systems: An overview of UPWARD's 1st phase research. $\underline{I n}$ : Proceedings on the $3^{\text {rd }}$ UPWARD Review and Planning Workshop. UPWARD, Los Baños, Laguna. Philippines

PRAIN, G. 1998. The potential for on farm conservation of rootcrop germplasm in the Philippines. In: Proceedings of MAFFPRCRTC International Workshop Sweetpotato Genetic Resources Conservation and Use in Asia. Baybay, Leyte, Philippines. R.L. Talatala-Sanico (ed).

TULIN, A.B., V.B. ASIO, D.M. CAMPILAN AND S. KAWAI. 2004. Characterization of nutrient deficiency symptoms in sweetpotato through farmer-scientist participatory approach. Ann. Trop. Res. 26(1 \& 2): 140-166 


\section{Acknowledgment}

The authors would like to thank CIP-UPWARD for the financial support of this study under the CIP-UPWARD Project entitled, "Integrated Nutrient Management for Sweetpotato Production in the Degraded Uplands of Pinabacdao, Samar with Dr. Anabelle B. Tulin as project leader. Likewise, they would like to acknowledge the important contributions of the late Dr. Jose R. Pardales, Jr., in the project as part of the project team.

\section{ABOUT THE AUTHOR}

Dr. Anabella B. Tulin finished her Doctor of Philosophy (Ph.D.) degree major in Soil Chemistry and Mineralogy from Iwate University, Japan as Mombusho Scholar. Presently, she is connected with the VSUbased PhilRootcrops as a professor of Soil Science and head of Soil and Environment Laboratory. She has conducted studies on Integrated Nutrient Management (NM) on rootcrops and on the effects of mineral nutrition on the growth and development of various rootcrops.

Dr. Victor B. Asio is a gradaute faculty and head of the Department of Agronomy and Soil Science, Visayas State University, Visca, Baybay, Leyte 